\title{
Penggunaan Bahasa Indonesia Pada Surat Resmi di Kantor Kementerian Agama Kota Cirebon
}

\section{Lilik Herawati $^{\mathrm{a}, 1}$ dan Indrya Mulyaningsih ${ }^{\mathrm{a}, 2}$}

${ }^{a}$ IAIN Syekh Nurjati, Cirebon, Indonesia

${ }^{1}$ lilikher74@gmail.com; ${ }^{2}$ indrya.m@gmail.com

\begin{tabular}{ll}
\hline Article info & A B S T R A C T \\
\hline $\begin{array}{l}\text { Article history: } \\
\text { Revised : } 17-09-2019-2019\end{array}$ & An official letter created and issued by an institution can be one \\
Accepted: 05-12-2019 & indicator, whether or not the institution. This study aims to \\
& City Religious Office. This descriptive qualitative research takes \\
& data in the form of letters issued from January to March 2019. \\
& Based on the analysis it can be concluded that the writing of the \\
& address, writing the name, writing the day, writing the affix, \\
& greeting, closing greeting, describing the description of time, \\
& lacking letters or words, particles, and pre-bound forms. The \\
& factors causing language errors, among others: copy-paste, do \\
& not know, not careful, and do not care. Therefore, it is \\
& recommended that socialization of PUEBI and KBBI V be \\
& implemented, Law No. 24 of 2009, training in writing official \\
& letters, and preparing guidelines for writing official letters.
\end{tabular}

Keywords:

KBBI

letter

PUEBI

Official

training
Surat resmi yang dibuat dan diterbitkan oleh suatu lembaga dapat menjadi salah satu indikator, baik tidaknya lembaga tersebut. Penelitian ini bertujuan untuk mendeskripsikan bahasa yang digunakan pada surat resmi Kantor Agama Kota Cirebon. Penelitian kualitatif deskriptif ini mengambil data berupa surat yang diterbitkan dari Januari sampai Maret 2019. Berdasarkan analisis dapat disimpulkan bahwa penulisan alamat, penulisan nama, penulisan hari, penulisan imbuhan, salam pembuka, salam penutup, pemerian keterangan waktu, kurang huruf atau kata, partikel, dan bentuk terikat pra-. Adapun faktor penyebab kesalahan bahasa, antara lain: salin tempel, tidak tahu, kurang teliti, serta tidak peduli. Oleh karena itu, disarankan agar dilakukan sosialisasi PUEBI dan KBBI V, penerapan UU No. 24 Tahun 2009, pelatihan penulisan surat dinas, serta penyusunan pedoman penulisan surat dinas.

Copyright $\odot 2019$ Institut Agama Islam Negeri Syekh Nurjati Cirebon.

\section{PENDAHULUAN}

Bahasa merupakan sarana komunikasi, baik antar-individu maupun antarlembaga. Komunikasi yang dilakukan dapat secara lisan maupun tulis. Komunikasi tulis yang dilakukan antar-lembaga biasanya melalui surat. Surat merupakan salah satu sarana yang digunakan sebuah organisasi atau lembaga untuk menyampaikan ide atau hal lain. Surat yang dikeluarkan oleh sebuah 
lembaga, dikategorikan sebagai surat dinas. Surat dinas berarti surat resmi yang menggunakan bahasa Indonesia sesuai kaidah (Tarigan, 2013). Artinya, surat dinas hendaknya ditulis dengan mengikuti kaidah baku. Hal ini sebagai salah satu cara agar isi surat mudah dimengerti. Oleh karena itu, tidak jarang bentuk surat pun memiliki sistematika dan format yang hampir sama (Fitriyani, 2017).

Surat dapat diidentikkan dengan lembaga yang mengeluarkan surat tersebut (Kunjana, 2008). Artinya, sebuah institusi dapat diketahui dari surat yang dikeluarkan, baik dari segi format, sistematika, maupun bahasa. Sebagian besar surat memiliki sistematika penulisan yang sama. Bahkan tidak jarang surat yang dibuat hanya hasil salin tempel. Maksudnya, surat itu sudah dibuat sebelumnya dan hanya tinggal mengganti waktu serta penanda tangan. Hal seperti inilah yang membuat surat menjadi janggal, terutama pada bahasa yang digunakan.

Bahasa Indonesia bersifat dinamis. Artinya, kosakata terus mengalami perubahan seiring perkembangan waktu. Contoh, pada kata 'apotik'. Beberapa waktu yang lalu, penulisan 'apotik' adalah benar. Namun sekarang tidak demikian. Penulisan 'apotik' yang benar seharusnya menggunakan huruf 'e' sehingga seharusnya tertulis 'apotek'. Untuk memastikan kebenaran ejaan sebuah kata dapat berpegang pada Kamus Besar Bahasa Indonesia Edisi V (KBBI V) dan Pedoman Umum Ejaan Bahasa Indonesia (PUEBI). Seiring perkembangan teknologi, KBBI V dan PUEBI dapat diakses bebas, baik secara daring maupun luring.

Beberapa penelitian telah dilakukan terkait keterampilan menulis surat. Hasanah, dkk (2018) menyimpulkan bahwasannya masih terdapat kesalahan pada kelengkapan bagian-bagian surat, kurang sesuainya antara isi dengan topik, diksi yang kurang tepat, serta ejaan yang tidak baku. Penelitian Noor dan Mulyani (2016) mencoba meningkatkan keterampilan siswa dalam menulis surat resmi melalui pendekatan keterampilan proses. Hasil penelitian menunjukkan adanya peningkatan dari sikap negatif menjadi positif. Penelitian Hasanah (2018) menujukkan bahwa surat resmi yang dikeluarkan oleh Kantor Desa Mamben Lauk terdapat kesalah pada: ejaan, diksi, dan kalimat yang kurang efektif.

Penelitian Wiguna, Ramaniyar, \& Kusnita (2016) menunjukkan bahwa surat dinas yang dibuat masih perlu perbaikan, terutama keefektifan kalimat, diksi, dan ejaan. Faisah (2018) menyimpulkan bahwa kesalahan surat dinas yang 
dikeluarkan oleh Kantor Kelurahan Layana Indah, meliputi: huruf kapital, ejaan, pemisahan kata, diksi, huruf miring, dan tanda baca. Berbagai cara telah dilakukan untuk meningkatkan keterampilan menulis surat dinas. Hal ini seperti yang dilakukan Suprapto (2018), yakni dengan pemodelan. Demikian juga penelitian Pardamean (2013) yang meningkatkan keterampilan menulis surat resmi dengan menggunakan latihan analisis.

Penelitian Amin dan Suyanto (2017) juga menyimpulkan bahwa surat undangan yang dibuat oleh organisasi kemahasiswaan memiliki dua kesalahan, yakni: ejaan dan tatabahasa. Hasil penelitian Prasetya (2019) juga menyimpulkan bahwa terdapat kesalahan ejaan dan diksi. Demikian juga dengan hasil penelitian Adiyasa, Artika, \& Rasna (2017). Hal ini tidak jauh berbeda dengan penelitian Lestari, Hadi, \& Meikayanti (2015) yang menyimpulkan bahwa kesalahan linguistik pada surat resmi Kantor Desa Teguhan, meliputi: morfologi, konjungsi, preposisi, dan diksi. Temuan di atas diperkuat dengan hasil penelitian Nurula'la (2015) yang menyimpulkan bahwa selain kesalahan ejaan, surat dinas juga memiliki kesalahan kalimat.

Penting kiranya dilakukan penelitian terkait bahasa yang digunakan pada surat dinas di Kantor Kementerian Agama Kota Cirebon. Hal ini selain dapat mengetahui sistematika dan format yang digunakan, juga dapat mengetahui bahasa yang digunakan. Penggunaan bahasa ini juga dapat dijadikan sebagai indikator kepedulian terhadap Undang-Undang No. 24 Tahun 2009 tentang Bendera, Bahasa, dan Lambang Negara, serta Lagu Kebangsaan.

\section{METODE}

Penelitian ini menggunakan desain kualitatif. Data yang terkumpul berupa bahasa yang digunakan dalam surat resmi yang dikeluarkan oleh Kantor Kementerian Agama Kota Cirebon. Data dikumpulkan melalui observasi dokumen. Adapun yang dianalisis adalah surat sejak Januari sampai Maret 2019. Data yang terkumpul akan dianalisis dengan teknik catat. Teknik analisis menggunakan model Miles\&Huberman (Sugiyono, 2016). Penelitian ini memerlukan waktu 5 bulan. 


\section{HASIL DAN PEMBAHASAN}

Data berupa surat yang diperoleh dari Kota Cirebon sebanyak 19 lembar, dengan rincian: Januari (5), Februari (8), dan Maret (5). Adapun temuan penelitian sebagai berikut.

\section{Penulisan Alamat}

Di surat tertulis 'Kepada Yth.' Seharusnya cukup ditulis 'Yth.'. Kata 'kepada' di KBBI V dimaknai sebagai kata depan untuk menandai tujuan orang. Seperti telah diketahui bersama bahwa surat dibuat adalah untuk ditujukan kepada seseorang. Oleh karena itu, penggunaan kata 'kepada' justru memiliki makna berlebihan. Berlebihan karena sudah jelas yang dituju adalah seseorang. Kesalahan ini ditemukan pada setiap surat. Artinya, dari 18 surat, semua memuat kesalahan yang sama, yakni menggunakan kata 'kepada'.

\section{Salam Pembuka}

Layaknya sebuah percakapan, sebuah surat pun pasti menyertakan salam pembuka. Beragam bentuk salam pembuka yang disampaikan. Namun jika merujuk pada Kantor Agama, maka salam pembuka menggunakan kata 'Assalamualaikum wr wb.'. Seperti telah diketahui bersama bahwa mayoritas penduduk Indonesia beragama Islam. Kosasata Islam banyak berasal dari Bahasa Arab. Demikian juga dengan salam. Di KBBI V, salam merujuk pada 'assalamualaikum wr wb.' Tanpa menggunakan apostrop.

Hal ini berbeda dengan salam pembuka di data. Semua surat menggunakan salam dengan tulisan “Assalamu'alaikum wr wb.'. Penulisan dengan menggunakan apostrop mengindikasikan bahwa bahasa tersebut adalah bahasa Arab. Artinya, salam tersebut ditulis dengan menggunakan bahasa asing. PUEBI mengatur bahwasannya semua kata yang berasal dari bahasa selain bahasa Indonesia maka harus ditulis dengan dicetak miring.

\section{Penulisan Nama}

Berdasarkan data yang diperoleh, semua surat menuliskan 'Kantor Kementrian Agama Kota Cirebon'. Kata 'kementrian' merupakan bentukan kata 'menteri' yang mendapat imbuhan 'ke-' dan '-an'. Oleh karena itu, 'kementrian' seharusnya ditulis 'kementerian'. Namun ternyata, di semua surat ditulis tidak demikian. 
Hal ini sebenarnya sangat sederhana, tetapi hal tersebut dianggap biasa dan bukan merupakan sebuah kesalahan. Hal ini terjadi karena sebelum diberlakukan KBBI V, kata 'mentri' memang baku dan benar. Namun seiring perjalanan waktu, kata 'mentri' telah bergeser dan diubah menjadi 'menteri'. Sekali pun hal tersebut dianggap sepele bagi sebagian orang, tetapi tidak bagi para staf di Kantor Agama Kota Cirebon. Artinya, bagi seseorang yang selalu mengikuti perkembangan bahasa, tentu keberadaan PUEBI dan KBBI V sangat membantu. Namu demikian, bagi staf yang tidak mengikuti perkembangan bahasa Indonesia, keberadaan PUEBI dan KBBI V merupakan hal yang tidak diketahui.

\section{Penulisan Hari}

Di Indonesia dikenal tujuh nama hari. Salah satunya adalah Jumat. Berdasarkan data dari seluruh surat dapat diketahui bahwa para staf menulis 'Jum'at' dengan menyertakan aprostop di atas. KBBI $\mathrm{V}$ dan PUEBI memberi rambu-rambu terkait penulisan berbahasa asing. Penulisan 'Jum'at' menandakan bahwa kata tersebut merupakan bahasa Arab atau bahasa asing. Oleh karena itu, cara menulisnya harus dengan dicetak miring. Hal ini tidak seperti yang tertulis di surat. Meskipun menggunakan apostrop, tetapi tidak ditulis dengan mencetak miring.

Hal ini juga dijumpai pada penulisan 'Al-Qur'an'. Kaidah penulisan seperti itu sama dengan penulisan hari 'Jumat'. Jika menggunakan apostrop, maka penulis surat sedang menggunakan bahasa Arab atau asing. Jika memang demikian, maka harus ditulis dengan dicetak miring. Namun jika ingin ditulis dengan huruf tegak, maka seharusnya apostrop dihilangkan sehingga menjadi 'AlQuran'.

Berdasarkan wawancara kepada staf Kantor Agama Kota Cirebon dapat diketahui bahwa kaidah seperti itu tidak diketahui sebelumnya. Para staf hanya menulis berdasarkan pengetahuan yang dimiliki dan berdasarkan contoh suratsurat sebelumnya. Hal ini menunjukkan bahwa para staf hendaknya juga perlu diberikan sosialisasi terkait keberadaan PUEBI dan KBBI V.

\section{Penggunaan Imbuhan}

Sebagian besar surat yang ditulis menggunakan kata 'sehubungan'. Kata 'sehubungan' merupakan bentukan dari kata dasar 'hubung' dan mendapat awalan 'se-' serta akhiran '-an'. Namun ternyata, imbuhan 'se- + -an' tidak ada dalam 
kaidah morfologi Bahasa Indonesia. Oleh karena itu, kata 'sehubungan' seharusnya tidak digunakan. Hal ini dapat dibuktikan bahwa di KBBI V, kata 'hubung' memiliki bentukan kata 'berhubung', 'berhubungan', 'hubungan', 'keterhubungan', 'memperhubungkan', 'menghubung-hubungkan', 'menghubungi', 'menghubungkan', 'penghubung', 'penghubungan', 'perhubungan', dan 'terhubung'.

Adapun pengganti kata tersebut adalah 'berhubungan' atau 'terkait'. Dalam KBBI V, berhubungan memiliki makna bersangkutan (dengan); ada sangkut pautnya (dengan). Oleh karena itu, seharusnya kata 'sehubungan' tidak digunakan.

\section{Penulisan Salam Penutup}

Selain salam pembuka. Surat juga selalu menggunakan salam penutup. Sama halnya dengan penulisan salam pembuka, salam penutup selalu diakhiri dengan kata 'wassalamualaikum wr wr.'. Namun demikian, terhadapat hal-hal yang harus diperhatikan bahwasannya kata tersebut merupakan adaptasi dari bahasa Arab. Adaptasi berarti sudah diserap dan dianggap sebagai bahasa Indonesia dengan penyesuaian. Adapun penyesuaian yang dimaksud adalah terkait penulisan atau ejaan. Jika masih dalam bahasa Arab, cara menulis kata tersebut dengan diberi tanda apostrop atau petik di atas. Namun setelah diserap dalam bahasa Indonesia, tanda tersebut tidak lagi ditulis.

PUEBI sudah mengatur cara menulis kata. Semua kata yang berasal dari bahasa Asing maka cara menulisnya harus dengan dicetak miring. Demikian juga ketika menuliskan salam penutup dengan menggunakan apostrop di atas maka itu berarti menggunakan bahasa Arab. Kata tersebut seharusnya ditulis dengan menggunakan kata dicetak miring, tetapi jika ditulis dengan menghilangkan apostropnya, maka kata tersebut ditulis dengan huruf tegak. Hal ini berarti salam penutup tersebut berasal dari bahasa Indonesia.

\section{Pemerian Keterangan Waktu}

Setiap surat pasti memberikan keterangan waktu. Terdapat beberapa hal yang perlu diperhatikan pada keterangan waktu. Pertama, rincian waktu yang berupa surat undangan, pada dasarnya merupakan bagian tak terpisahkan dari pernyataan sebelumnya. Artinya, bagian yang menyatakan hari, tanggal, pukul, 
dan tempat merupakan bagian dari pernyataan sebelumnya. Oleh karena itu, cara menulisnya hendaknya tidak diawali dengan huruf kapital.

Kedua, penulisan '... bulan Januari'. Januari merupakan penunjuk waktu berupa bulan. Penggunaan kata 'bulan' pada penggalan tersebut justru salah dan berlebihan. Oleh karena itu, seharusnya ditulis '... Januari' dengan menghilangkan kata 'bulan'.

Demikian juga dengan keterangan waktu, misalnya: 'dari pukul 09.00 WIB s/d 12.00 WIB'. Penulisan 's/d' tidak berterima di PUEBI. Oleh karena itu, seharusnya ditulis dengan 's.d.'. Kaidah penulisan ini juga hampir ditemukan di setiap surat yang dibuat oleh Kantor Agama Kota Cirebon.

Pada beberapa surat masih digunakan kata 'jam' sebagai penunjuk waktu. KBBI V menyatakan bahwa jam adalah alat untuk mengukur waktu. Oleh karena itu, seharusnya menggunakan kata 'waktu' untuk merujuk keterangan waktu. Meskipun demikian, masih banyak kekeliruan yang digunakan antara penggunaan kata 'waktu' dan 'jam'.

\section{Penulisan Partikel}

Bahasa Indonesia mengenal kata partikel. Salah satunya adalah 'di'. Banyak kesalahan penulisan pada kata partikel 'di'. Misalnya kata 'dibawah' dan 'di bawah'. Sebagian besar masyarakat Indonesia belum dapat membedakan cara menulis 'di' dengan dipisah dan dirangkai. Demikian juga surat yang ditulis oleh Kantor Agama Kota Cirebon. Penulisan 'di’ dirangkai jika tidak menunjukkan tempat. Itu artinya, 'di’ berfungsi sebagai imbuhan. Adapun prinsip penulisan sebuah imbuhan adalah selalu dirangkai dengan kata yang mengikutinya.

Namun hal ini berbeda dengan 'di' yang berfungsi sebagai partikel atau kata depan. Misalnya kata 'di bawah'. Kata 'di' harus ditulis terpisah dari kata 'bawah'. Hal ini karena kata 'bawah' menyatakan tempat. Ini artinya 'di' bukan sebagai imbuhan, tetapi sebagai partikel atau kata depan.

\section{Kurang Huruf atau Kata}

Selain faktor ketidaktahuan, kesalahan bahasa pada surat dinas di Kantor Agama Kota Cirebon juga disebabkan karena faktor kurang teliti. Hal ini misalnya dapat diketahui dari kata 'mempehatikan'. Semua orang juga akan tahu bahwa kata yang dimaksud adalah 'memperhatikan'. Di KBBI V, kata 'memperhatikan' memiliki makna mengamati atau mencermati. Adapun kata 'mempehatikan' tidak 
ditemukan di KBBI V. Hal ini menunjukkan bahwa penulis surat kurang teliti dalam mengetik.

\section{Penulisan Bentuk Terikat Pra}

Bahasa Indonesia mengenal kata 'pra-', 'kontra-', 'pasca-','anti-', dan sebagainya. Kata-kata tersebut pada dasarnya adalah imbuhan yang berasal dari bahasa asing. Seperti telah dibahas pada bagian sebelumnya, bahwa cara menulis imbuhan adalah dirangkai dengan kata yang mengikutinya. Oleh karena itu, di surat yang berbunyi '...pra manasik' seharunya ditulis serangkai sehingga menjadi ‘...pramanasik'. Namun demikian, masih banyak cara menuliskan bentuk terikat tersebut dengan dirangkai.

\section{Faktor Penyebab Kesalahan Bahasa}

Demi mendapatkan informasi terkait kesalahan yang dilakukan pada bahasa surat dinas, maka dilakukanlah wawancara kepada staf di Kantor Agama Kota Cirebon. Berdasarkan wawancara diperoleh hasil sebagai berikut.

1. Mengulang dari sebelumnya

Beberapa kesalahan bahasa yang terjadi lebih karena hasil kopi tempel. Maksudnya, surat tersebut merupakan surat yang telah dibuat dan diterbitkan juga beberapa waktu sebelumnya. Staf yang mendapat tugas membuat surat tersebut hanya mengganti keterangan waktu. Adanya anggapan bahwa surat ini sebelumnya sudah dibuat maka diasumsikan sudah benar dan terhindar dari kesalahan. Dalam hal ini, pimpinan juga tidak terlalu mengoreksi karena dianggap sudah benar dan telah dilakukan sejak beberapa waktu yang lalu. Bahkan dapat dikatakan surat tersebut merupakan perulangan setiap tahun. Asumsinya, jika pada tahun atau waktu sebelumnya sudah beredar maka berarti surat tersebut sudah benar. Hal inilah yang melatarbelakangi keberadaan surat tersebut.

2. Tidak tahu

Namun demikian, kesalahan bahasa yang digunakan juga disebabkan factor ketidaktahuan. Staf yang mendapat tuga untuk membuat surat, tidak mengetahui bahwa bahasa Indonesia telah mengalami perubahan. Baik staf maupun pimpinan tidak mengetahui keberadaan Pedoman Umum Ejaan Bahasa Indonesia (PUEBI) atau Kamus Besar Bahasa Indonesia edisi V (KBBI V). Staf membuat surat perpedoman pada surat yang pernah diterbitkan, seperti 
faktor nomor 1. Selain itu, staf juga membuat surat berdasarkan pengetahuan yang diperoleh sebelumnya, misalnya ketika sekolah. Hal ini dikarenakan bekum adanya sosialisasi tentang PUEBI dan KBBI V.

3. Kurang teliti

Faktor selanjutnya adalah kurang teliti. Hal ini biasanya terjadi karena surat yang harus segera diedarkan atau pimpinan yang ada kepentingan dinas lain. Keadaan tersebut menjadikan surat dibuat dengan terburu-buru dengan tidak memerhatikan kaidah bahasa Indonesia. Meskipun faktor ini tidak sering dilakukan, tetapi pernah dilakukan.

4. Kurang peduli

Faktor lain yang juga sering dilakukan adalah kurang peduli. Para staf maupun pimpinan kadang tidak peduli dengan bahasa yang digunakan pada surat dinas. Prinsip bagi pengirim atau pembuat surat adalah penerima surat dapat mengerti isi surat. Pun semua ini dilakukan juga arena tidak ada yang keberatan dengan bahasa yang digunakan. Hal tersebut menjadikan adanya anggapan bahwa bahasa yang digunakan pada surat dinas adalah sudah benar dan tidak bermasalah.

Berdasarkan faktor-faktor tersebut dapat disimpulkan bahwasannya perlu ada:

1. sosialisasi PUEBI dan KBBI kepada seluruh aspek masyarakat. Salah satunya adalah Kantor Agama. Walau bagaimana pun, lembaga resmi pemerintah hendaknya menjadi contoh dalam penggunaan bahasa Indonesia yang baik dan benar. Kaidah kebenaran berbahasa telah diatur di kedua buku tersebut. Olrh karena itu, sudah menjadi kewajiban jika Kantor Agama sebagai salah satu lembaga pemerintah juga memiliki, memahami, dan menggunakan serta menerapkan keduanya dalam bersurat resmi;

2. pentingnya menerapkan kaidah berbahasa Indonesia. Undang-Undang No. 24 Tahun 2009 mengatur tentang Bendera, Bahasa, dan Lambang Negara, serta Lagu Kebangsaan. UU ini mengamanatkan bahwasannya lembaga pemerintah harus menggunakan bahasa Indonesia dalam memberikan pelayanan kepada masyarakat. Salah satu layanan yang diberikan adalah dalam bentuk surat dinas. Adapun kaidah berbahasa Indonesia dapat dipelajari di PUEBI dan KBBI V, baik edisi luring maupun daring. 
3. pelatihan penulisan surat dinas. Menilik dari berbagai faktor kesalahan tersebut, perlu kiranya dilakukan pelatihan penulisan surat dinas, baik untuk staf maupun pimpinan. Hal ini sebagai upaya memberikan pelayanan yang baik kepada masyarakat. Selain itu, kondisi bahasa yang dinamis menjadikan ilmu tentang bahasa juga ikut berkembang. Oleh karena itu, para staf dan pimpinan perlu diberikan pelatihan sebagai saran untuk memperbarui ilmu yang selama ini dimiliki.

4. pedoman penulisan surat dinas. Selain itu, perlu adanya pedoman penulisan surat dinas yang diterbitkan oleh lembaga terkait. Artinya, meskipun samasama dari Kantor Agama, tetapi setiap kota atau kabupaten dapat memiliki pedoman tersendiri sesuai dengan wilayah kerja. Pedoman penulisan surat ini dapat menjadi pegangan bagi para staf dan pimpinan dalam menulis surat dinas. Jika Kantor Agama sudah memiliki pedoman penulisan surat, hendaknya juga selalu diperbarui mengikuti perkembangan bahasa Indonesia yang terbaru.

Beberapa uraian di atas diharapkan dapat meminimalisasi kesalahan bahasa pada surat dinas.

\section{SIMPULAN}

Berdasarkan analisis dapat disimpulkan bahwa penulisan alamat, penulisan nama, penulisan hari, penulisan imbuhan, salam pembuka, salam penutup, pemerian keterangan waktu, kurang huruf atau kata, partikel, dan bentuk terikat pra-. Adapun faktor penyebab kesalahan bahasa, antara lain: salin tempel, tidak tahu, kurang teliti, serta tidak peduli. Oleh karena itu, disarankan agar dilakukan sosialisasi PUEBI dan KBBI V, penerapan UU No. 24 Tahun 2009, pelatihan penulisan surat dinas, serta penyusunan pedoman penulisan surat dinas.

\section{UCAPAN TERIMA KASIH}

Terima kasih disampaikan kepada Kementerian Agama melalui IAIN Syekh Nurjati Cirebon karena telah membantu penelitian ini dengan memberikan Dana Bantuan Penelitian Tahun 2019. 


\section{DAFTAR PUSTAKA}

Adiyasa, I.Kd.D., Artika, I.W.,\& Rasna, I.W. (2017). Penggunaan Bahasa Indonesia pada Surat Dinas di Kantor Perbekel Desa Penglumbaran Kabupaten Bangli serta Implikasinya terhadap Pembelajaran Menulis Surat di Sekolah. Jurnal Pendidikan Bahasa dan Sastra Indonesa, 7(2), 1 -10.

Amin, M.F. \& Suyanto. (2017). Analisis Kesalahan Berbahasa dalam Penulisan Surat Undangan Organisasi Kemahasiswaan di Faklutas Ilmu Budaya Universitas Diponegoro. Nusa, 12(2), $34-41$.

Faisah, N. (2018). Analisis Kesalahan Berbahasa Indonesia Dalam SuratMenyurat di Kantor Kelurahan Layana Indah. Jurnal Bahasa dan Sastra, $3(3), 1-8$.

Fitriyani, D. (2017). Pelatihan Penulisan Surat Dinas di Pekon Banyu Urip. Jurnal Bagimu Negeri, 1(1), 21 - 29.

Hasanah, N., Indihadi, D, \& Muiz, D.A. (2018). Keterampilan Menulis Surat Resmi Berdasarkan Analisis Konstruksi Surat. Pedadidaktika: Jurnal Ilmiah Pendidikan Guru Sekolah Dasar, 5(2), 41 - 46.

Hasanah, N. (2018). Analisis Kesalahan Gramatika Bahasa Indonesia Dalam Surat Resmi di Kantor Desa Mamben Lauk. Prasasti: Journal of Linguistics, 3(1), $98-112$.

Kunjana, R. (2008). Surat - Menyurat Dinas. Yogyakarta: Pustaka Book Publisher.

Lestari, N.H., Hadi, P.K., \& Meikayanti, E.A. (2015). Analisis Kesalahan Berbahasa dalam Tataran Linguistik pada Surat-Surat Resmi di Kantor Desa Teguhan Kecamatan Paron Kabupaten Ngawi. Widyabastra, 3(2), 66 - 75.

Noor, S.H. \& Mulyani, M. (2016). Peningkatan Keterampilan Menulis Surat Resmi Melalui Pendekatan Keterampilan Proses. Jurnal Pendidikan Bahasa dan Sastra Indonesia, 5(2), 35 - 41.

Nurula la. (2015). Analisis Kesalahan Bahasa Indonesia pada Surat Masuk di SMP Negeri 1 Peudawa. Metamorfosa, 3(1), 1 - 12.

Pardamean, A. S. (2013). Peningkatkan Keterampilan Menulis Surat Resmi dalam Bahasa Jerman melalui Pola Latihan Analisis. Jurnal Bahas, 85(39), 1 - 14.

Prasetya, A.D.A. (2019). Analisis Kesalahan Ejaan dan Pilihan Kata pada Surat Dinas di SKTIP Al Hikmah Surabaya. Lingua Franca: Jurnal Bahasa, Sastra, dan Pengajarannya, 3(1), 120 - 127.

Sugiyono. (2016). Metode Penelitian Kuantitatif, Kualitatif, dan R\&D. Bandung: Alfabeta. 
Suprapto. (2018). Upaya Meningkatkan Keterampilan Menulis Surat Dinas dengan Pendekatan Kontekstual Pemodelan Siswa Kelas VIII A SMP Negeri 2 Piyungan, Bantul. Caraka, 4(2), 16 - 33.

Tarigan, H.G. (2013). Menulis sebagai Suatu Keterampilan Berbahasa. Bandung: CV Angkasa.

Wiguna, M.Z., Ramaniyar, E., \& Kusnita, S. (2016). Analisis Bentuk Surat Dinas Program Studi Pendidikan Bahasa dan Sastra Indonesia Tahun Akademik 2013/2014 Semester Genap. Jurnal Edukasi, 14(1), 94 - 107. 